3. Кыверялг А. А. Методы исследования в профессиональной педагогике. Таллинн : Валгус, 1980. 334 с.

4. Сисоєва С. О., Кристопчук Т. С. Педагогічний експеримент в наукових дослідження неперервної професійної освіти : навчально-методичний посібник. Луцьк : Волинська обласна друкарня, 2009. 460 с.

5. Сурмін Ю. П. Майстерня вченого: підручник для науковця. Київ : Консорціум з удосконалення менеджменту освіти в Україні, 2006. 302 с.

\title{
References:
}

1. Gershunsky B. S . Obrazovatelno-pedagogicheskaya prognostika. Teoriya, metodologiya, practica. M .: Nauka, 2003.768 s. [Educational and pedagogical forecast. Theory, methodology, practice. M .: Science, 2003. 768 p.]

2. Goncharov S. M, Gurin V. A. Metodi i technologii navchaniya v kreditno-transferniy sistemi organizacii navchalnogo procesu: navch.-metod. Posib. Rivne: NUGP, 2010. 451 s. [Learning methods and technologies in the system of credit transfer of the organization of educational process: educational method. tool. Exactly: NUGP, 2010. 451 p.]

3. Kiveralg A. A Metodi isledovaniya v profesionalnoy pedagogike. Tallin: Valgus, 1980. $334 \mathrm{~s}$. [Methods of research in professional pedagogy. Tallinn: Valgus, 1980. 334 p.]

4. Sysoeva S. O, Kristopchuk T. E Pedagogichniy experiment v naukovih doslidjeniyah neperervnoi profesiynoii osviti: navch.metod. posib. Lutsk: Volinska oblasna druksrnya, 2009. 460 s. [Pedagogicall experiment in scientific studies of continuing vocational education: a teaching method. tool. Lutsk: Volyn Regional Printing House, 2009. 460 p.]

5. Surmin Y. P. Maysterniya vchenogo: pidruch. dlya naukovtsa. K: Navch.-metod. Centr «Konsorcium z udoskonalenya menedjmentu osvity v Ukraini»,2006. 302 s. [Scientific Workshop: a textbook. for the scientist. K: The teaching method. Consortium Center for the Improvement of Educational Management in Ukraine, 2006. 302 p.]

Tkachuk $O$. M. Analysis of the results of formation of the professional competence of future nursing professionals to organize primary HIV infection with student young people.

The most important stage of scientific analysis of professional training of future specialists in nursing (FSN) in order to build their professional competence in organizing primary prevention of HIV infection among student youth, a pedagogical experiment is one of the most effective ways to objectively test the validity of a research hypothesis.

The study conducted experimental work aimed at enhancing the professional effectiveness of future FSiN to the primary occupational activity of HIV among student youth.The stages of carrying out pedagogical experiment (ascertaining, forming, final) are considered.

Experimental work on checking the effectiveness of pedagogical conditions and structural and functional model of formation of professional competence of future FSiN to organize primary prevention of HIV infection among student youth was conducted in the period 2017-2020. in four medical education institutions.

Pedagogical monitoring of professional competence formation of future FSiN to organize primary prevention of HIV infection among student youth was carried out using a set of diagnostic methods, which allowed to study the course and results of gradual development of all components of professional competence and to observe the dynamics of its formation in students. The integrity and effectiveness of the diagnostic apparatus used to assess the level of formation of a certain professional competence, provided by the gradual formation of its components by specified indicators, best accumulates individual diagnostics, including the author's, and allows full display of the competence of the process organization of primary prevention of HIV infection among student youth in medical institutions of education.

Key words: professional competence, future specialists in nursing, primary prevention, HIV infection, students, experiment, ascertainment, formative, final stages.

UDC 378:364-43

DOI https://doi.org/10.31392/NPU-nc.series5.2020.73-2.23

Tuliakova K. R.

\section{ENGLISH LANGUAGE FOR FUTURE SPECIALISTS IN THE FIELD OF MEDIATION AND CONFLICT REGULATION}

The article deals with the process of formation of future professionals in the field of mediation and conflict resolution of English-speaking professionally-oriented competence in monologue speech using authentic video materials.

The purpose of the article is to create methodological recommendations for teachers of the Universities or Academies of Ukraine in order to effectively form and develop English-language professionally oriented competence in monologue speech. The author impresses to adapt the proposed model of the organization of teaching English-language vocational monologue speech to the content of educational modules, as well as different conditions of study in higher education institutions of Ukraine. The author also proposes a general algorithm of teacher's activity for forming English-language professional competence in monologue speech using authentic video materials. Also are named the learning approaches that have been guided in the development of educational process recommendations.

The author proposes to take into account the functions performed by the mediator in their professional activity when selecting authentic video materials such as diagnostic, organizational, educational and informational, supportive, broadcast, conciliatory. There are three structural components of monologue-reasoning, monologue-description, and monologuepersuasion: Posing a Problem; Logical Substantiation of Reflections and Conclusion in the article. The article substantiates the use of a set of exercises for teaching this type of monologue speech according to the stages of training: informative I complex of exercises; research-search-II complex of exercises and presentation - III complex of exercises. Examples of exercises for each stage are provided. 
The author concentrates on the stages of students' individual work. Briefly describes this type of educational activity on external and internal characteristics. The article also deals with the preparation and execution of some types of the individual work. It is said that the peculiarities of this type of work are planning in the allotted time and variety of organizational forms (work in pairs or individual student activity), the availability of specific results, written, oral or combined form.

Key words: monologue speech, mediation, authentic videos, conflict modeling technology, individual work, activity algorithm, monologue structure.

\section{(статтю подано мовою оригіналу)}

We believe that the process of formation of future professionals in the field of mediation and conflict regulation of English-language professional competence in monologue speech using authentic video materials should be applied from the fifth year of study, because it is at this stage of training is developing professional communication skills. Students must have the skills of a monologue on relevant professional topics, be able to substantiate their position and provide the necessary information. The term "Vocational training" is interpreted by Collins English Dictionary as a term referring to the profession and special education courses that develop professional skills.

Defining the competencies of any specialist is the answer to a public inquiry in the preparation of these specialists. Within the project of Quality Assurance of Mediation Services through Standardization of Requirements for Basic Training of Mediators, implemented by the National Association of Mediators of Ukraine and with the participation of other public organizations that unite Ukrainian mediators, with the support of the American people provided through the United States Agency for International Development (USAID ) within the framework of the New Justice Program, the standard "Basic Principles of Teaching Basic Mediator Skills. The standard regulates the competence of the future specialist in the field of mediation and conflict regulation.

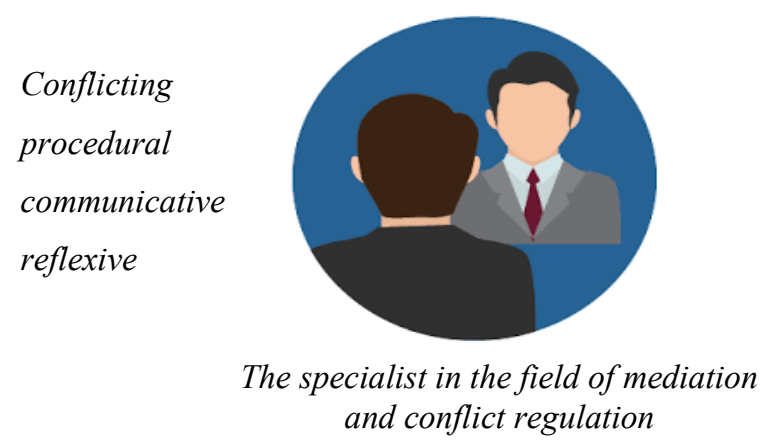

Figure 1. The competence of a specialist in mediation and conflict regulation

The purpose of the article is to create methodological recommendations for teachers of Ukraine in order to effectively implement the proposed methodology for the formation of English-speaking professionally oriented competence in monologue.

In order to understand the optimal ways of implementing the developed methodology, it is necessary to outline explanations and wishes for the organization of the educational process. The technique of forming English-speaking professionally oriented speech in future specialists in the field of mediation and conflict resolution is developed within the framework of the discipline "English for professional communication". It is consistent with topics that are covered in practical English lessons, for example, «The history of leisure», «Personal recognition at work», «Social change and social conflict», «Social movements», «Alexis de Tocqueville's study», «Iranian revolution», «Education», «Education and equality», «Norms of behavior», «The notion of "Punctuality"», «Capitalism and socialism», «How does capitalism work?», « Society and history», «Society issue» [1, p. 62]. proposes a general algorithm of teaching activity for the formation of English-speaking professionally-oriented competence in English professionally oriented spoken production using authentic video materials.

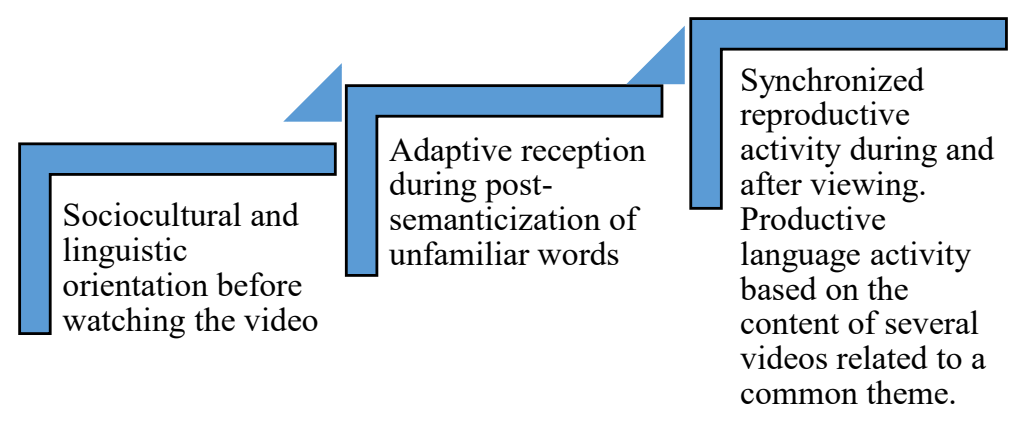

Figure 2. Teacher Activity Algorithm for English professionally oriented spoken production based on Using Authentic Video 
We consider that certain approaches as communicative, competent, activity-oriented, informational, cultural and sociological, implicit should be followed in the learning process. The process of realization of EPOSP (English professionally oriented spoken production) features at the presentation stage of students' work should also be monitored: one-sided nature of expression, preparedness, certain duration in time, individual compositional construction, compositional completeness and overall structural integrity of expression. Such future specialists should not only have certain knowledge, but also be able to convey clearly and consistently to their interlocutor, construct relatively long, logical statements, describe events, phenomena, analyze and explain facts, present arguments to achieve the desired result and establish partnerships.

To attract foreign language and culture, you can use video materials on various topics. However, it is worth distinguishing between educational videos and authentic ones. The educational video means thematically organized, adequate training videos, which are often trained methodologists, then authentic videos are not edited. The highest level of involvement in a foreign language culture can be achieved through the use of only authentic materials documentaries and sci-fi films and subjects, which as well as the dynamism of the image, are considered by modern scholars and practitioners to be the most effective and promising means of learning a foreign language [3, p. 152]. The authentic video materials help students to observe how the native speakers are lexically designed their statements.

Video training can last from 45 minutes to 1 hour, but short video lengths are preferred: 30 seconds to 5-10 minutes, with 4-5 minutes of video demonstration being able to ensure the group's hard work throughout the hour. This is due to such a specific feature of the video. Therefore, authentic video materials can be used to teach all kinds of language activities, especially when learning to hear and speak the language, and also to remember the phonetic norms at a subconscious level while watching authentic video.

We have to admit that the use of video is psychologically justified: it is because of sight and hearing that a person receives the bulk of information.

In addition, authentic videos reflect real life, live broadcasting with its dialectical and social differences, its own pace of broadcasting, emotional coloring - all this evokes positive emotions, nourishes interest in language and culture, which activates the work of the limbic system of the human body and the process of the body training and motivation. The authentic videos help to increase students' motivation - they have a sense of success when they are able to understand and then translate into native language material that is intended for native speakers [4, p. 12]

Based on textbooks for teaching English (ESP), highlighting topics for the professional communication of future specialists in the field of mediation and conflict resolution, in order to improve the training of English spoken production and improve its effectiveness and quality, we chose the tool of teaching the model of conflict technology.

Teaching technology - a set of techniques of scientific work aimed at achieving the goals. Technology in training - use in the process of learning TTT (technical training tools) [2, p. 124-125].

The conflict modeling technology is based on problem-based learning methods: partial search, reproductive, passive material presentation, research method. Consider the concept of "conflict". A word of Latin origin meaning "collision". It is associated with aggression and threats by the public, making conflict a negative phenomenon that needs immediate resolution. However, we understand conflict as an opportunity to discover different perspectives on a particular phenomenon or event, as an element to identify alternatives, and an additional source of information; as a process that can be managed and controlled with the necessary techniques.

Modeling is based on the study of basic properties of the existing features of the studied objects and processes based on their quantitative characteristics and assessment of the dynamics of the event, as well as clarification of the main structural elements of the simulated phenomenon.

Also teachers have to remember about reflection. Reflection is the participant's awareness of communicating how he is perceived by his partner. The main essence of reflection is the following interpretation: I know what he represents me and why he thinks so. In order to provide an objective approach to solving the problem, you need to analyze your own position and your opponent's position. Social psychologists have proven that the completeness of a person's ideas about himself is largely determined the richness of his/her ideas about other people, the breadth and variety of his/her social relations.

Thus, the knowledge, skills and competencies required for conflict modeling technology help future professionals in the field of mediation and conflict resolution to manage conflicts. The concept of "conflict" and "conflict situation" should be distinguished. Conflict (dispute) - the emergence of different views during the discussion. If the principles of mutual respect and the interests of the participants of the discussion are violated, the conflict situation becomes a conflict.

People constantly negotiating and resolving conflict throughout all of their professional and personal life. It is likely that conflict will be an even greater component of organizations in near future. Teachers have shown that negotiation skills are among the most significant determinants of career success in our case - future specialists in the field of mediation and conflict resolution. There are specific techniques that anyone can learn. Understanding these techniques and developing some skills will be a critical component of your career success and personal success.

In general, we start by identifying the best and worst possible outcomes, and then specify possible increments that trade-offs can reflect, and finally, consider how the increments relate to the key issues. 
Techniques you can use:

- Broadening the Pie: first of all, create additional resources so that both sides can obtain their major goals, ask questions instead of making statements;

- Nonspecific Compensation: One side gets what it wants and the other is compensated on another issue;

- Logrolling Each person makes concessions on low-priority issues in exchange for concessions on issues that it values more highly;

- Unexpected techniques: you can ask credible advice, ask an unexpected question about something else, also a compliment may be important. The main thing is that requests, memories, compliments shifted the anger of an angry partner from the negative emotions to the positive.

There is no one "best" technique; each of us try to find a style that is comfortable for us. Everyone can negotiate successfully; everyone can reach agreements where all sides feel at least some of their needs have been satisfied. This involves a lot of alertness, active listening, good communication skills, great flexibility, good preparation, and above all it involves a sharing of responsibility for solving the problem.

Also we propose to pay attention to the structural component that has common features of English-speaking professional-oriented monologue-reasoning, monologue-description and monologue-persuasion on professional topics with such components as Posing a Problem, Logical Substantiation of Reflections and Conclusion. There is an important lesson to take away from this: teachers must pay closer attention to how EPOSP are implemented in practice and evaluate it. The educational resources also require the four levels of evaluation. The first three levels can help with specification of the outcome variable(s) by identifying 1) the desired results of treatment 2) the behaviors necessary to achieve these results, and 3) the attitudes, knowledge or skills that could produce the desired behaviors. The fourth level deals with details of implementation how to present the intervention to participants so that they react favorably to it.

Whereas EPOSP has been influential across the social sciences, advancing conceptions of social justice and democratic governance based on communicative rationality [5, p. 120-125]. It has always stood in a tenuous relationship to mediation.

Research on mediation tends to focus on the creative aspects of people's accounts about mediated texts while downplaying the nature of the texts that are being interpreted by audiences, as well as the broader structuralinstitutional and psychological-cultural constraints that play on and may further constrain the production of identity.

EPOSO also includes an individual work, a special type of educational activity, characterized by certain external and internal characteristics. External features: 1) setting teacher assignment, assisting and supervising; 2) lack of direct involvement from the teacher. Internal signs of the individual work:1) student's activity aimed at achieving a specific goal, getting specific results; 2) multilevel structure of students' educational and cognitive activity.

Individual work is planned at a designated time and is characterized by a variety of organizational forms (work in pairs or individual student's activity), availability of specific results, written, oral, or combined.

There are three stages of training EPOSO: informative, exploratory search and presentational. The informative stage consists of conditionally communicative tasks; the exploratory search includes receptive-reproductive tasks and the presentational stage - reproductive communicative tasks.

Conclusions. Thus, we recommend to develop the exercises, taking into account the requirements for the professional training of future professionals in the field of mediation and conflict regulation to ensure the possibility of effective cooperation with foreign colleagues.

It should be noted that the use of this type of work increases the motivation to study in general and to learn English in the professional field in particular.

As mentioned in the article, authentic video and conflict modeling technology mean to prepare lessons which make the students become more active and think critical about different topics. Using different teaching methods belongs to a modern way of teaching, that give the opportunity to work with foreign partners together using English. For future specialists in the field of mediation and conflict resolution it is important to make compromises. Surely, understanding these techniques and developing some skills are useful to make new experiences, gain knowledge and learn interesting things for future career.

Modern specialists in the field of mediation and conflict resolution perform all activities and develop different skills, special attention is paid to developing English professionally oriented spoken production, collaboration, and active learning.

\section{Bibliography:}

1. Бичкова Н. І. Нові стратегії використання відеофонограми для навчання усного іншомовного спілкування. Педагогічний прочес: Теорія і практика. 2006. Вип. 3. С. 69-79.

2. Методика навчання іноземних мов і культур: теорія і практика : підручник / О. Б. Бігич та ін. ; за заг. ред. С. Ю. Ніколаєвої. Київ : Ленвіт, 2013. 590 с.

3. Савицкая Н. С., Даниленко Р. М. Использование аутентичных видеоматериалов при формировании навыков говорения на занятиях по иностранному языку. Филологические науки. Вопросы теории и практики. 2011. № 2(9). С. 152-153.

4. Смирнов И. Я. Развитие устной речи учащихся на основе аутентичного художественного фильма. Иностранные языки в школе. 2006. № 6. С. 11-14.

5. Crossley M. \& Roberts M. (Eds). After Habermas: New perspectives on the public sphere. London., 2000. 179 p. 
6. Gilmore A. Catching Words. Exploiting Film Discourse in the Foreign Language Classroom.

7. Mishan F., Chambers A. (Eds.) Perspectives on Language Learning Materials Development. Oxford : Oxford Univ. Press, 2010. P. 111-148.

8. Sherman, J. Using Authentic Video in the Language Classroom. Cambridge : Cambridg.

9. Gilmore A. Catching Words. Exploiting Film Discourse in the Foreign Language Classroom.

10. Mishan F., Chambers A. (Eds.) Perspectives on Language Learning Materials Development. Oxford : Oxford Univ. Press, 2010. P. 111-148.

11. Sherman J. Using Authentic Video in the Language Classroom. Cambridge : Cambrid.

12. Gilmore A. Catching Words. Exploiting Film Discourse in the Foreign Language Classroom.

13. Mishan F., Chambers A. (Eds.) Perspectives on Language Learning Materials Development. Oxford : Oxford Univ. Press, 2010. P. 111-148.

14. Sherman J. Using Authentic Video in the Language Classroom. Cambridge : Cambr.

15. Crossley, M., \& Roberts, M. (Eds.). (2004). After Habermas: New perspectives on the public sphere. London: Blackwell [in English]

\section{References:}

1. Bychkova, N. E. (2006) Novi Stratehiyi Vykorystannia Videofonogramy dlia Navchannia Usnoho Inshomovnoho Spilkuvannia [New Strategies of Teaching Oral Speech Communication with Video]. Pedohohichnyi Protses: Teoriia i Praktyka-Pedagogical Process: Theory and Practice, 3,69-79 [in Ukrainian]

2. Bigych, O. B, Borysko, N. F, Boretska, G. E. et.al. (2013). Metodyka navchannia inozemnykh mov i kultur: teoriia i praktyka [Methodology of teaching foreign languages and cultures]. S.Y. Nikolayeva (Ed.). Kyiv: Lenvit [in Ukrainian].

3. Savitskaya, N. S., \& Danilenko, R. M. Ispolzovanye autentychnykh vydeomateryalov pry formyrovanyy navykov hovorenyia na zaniatyiakh po ynostrannomu yazyku [The use of authentic video materials in the formation of speaking skills in classes in a foreign language]. Fylolohycheskye nauky. Voprosy teoryy y praktyky - Philological science. Questions of theory and practice,2(9), Tambov: Gramota [in Russian].

4. Smirnov, I. Ya. (2006). Razvytye ustnoi rechy uchashchykhsia na osnove autentychnoho khudozhestvennoho fylma [The development of students' spoken language based on an authentic feature film]. Ynostrannye yazyky v shkole-

5. Foreign languages at schools, 6,11-14 [in Russian].

6. Gilmore, A. Catching Words. Exploiting Film Discourse in the Foreign Language Classroom [Text] / A. Gilmore;

7. F. Mishan, A. Chambers (Eds.) // Perspectives on Language Learning Materials Development. - Oxford: Oxford Univ. Press, 2010. - P. 111-148.

8. Sherman, J. Using Authentic Video in the Language Classroom [Text] / J. Sherman. - Cambridge: Cambridg

9. Gilmore, A. Catching Words. Exploiting Film Discourse in the Foreign Language Classroom [Text] / A. Gilmore;

10. F. Mishan, A. Chambers (Eds.) // Perspectives on Language Learning Materials Development. - Oxford: Oxford Univ. Press, 2010. - P. 111-148.

11. Sherman, J. Using Authentic Video in the Language Classroom [Text] / J. Sherman. - Cambridge: Cambrid

12. Gilmore, A. Catching Words. Exploiting Film Discourse in the Foreign Language Classroom [Text] / A. Gilmore;

13. F. Mishan, A. Chambers (Eds.) // Perspectives on Language Learning Materials Development. - Oxford: Oxford Univ. Press, 2010. - P. 111-148.

14. Sherman, J. Using Authentic Video in the Language Classroom [Text] / J. Sherman. - Cambridge: Camb

15. Crossley, M., \& Roberts, M. (Eds.). (2004). After Habermas: New perspectives on the public sphere. London: Blackwell [in English]

\section{Тулякова К. Р. Англійська мова для майбутніх фахівців у сфері медіації та врегулювання конфліктів}

У статті розповідається про процес формування у майбутніх фахівцฺів із медіації та врегулювання конфліктів англомовної професійно орієнтованої компетентності в монологічному мовленні з використанням автентичних відеоматеріалів. Метою статті є створення методичних рекомендацій для викладачів ЗВО Украӥни для ефективного формування та розвитку англомовної професійно орієнтованої компетентності в монологічному мовленні. Авторка пропонує адаптувати запропоновану модель організації навчання англомовного професійно орієнтованого монологічного мовлення до змісту навчальних модулів, а також різних умов навчання у закладах вищої освіти України. Також авторка пропонує загальний алгоритм діяльності викладача для формування англомовної професійно орієнтованої компетентності в монологічному мовленні з використанням автентичних відеоматеріалів. Названо підходи до навчання, якими керувалися під час розроблення рекомендацій щзодо навчального процесу.

Окрім того, у статті згадуються структурні компоненти монологу-переконання/міркування та монологу-опису, а саме: постановка питання, логічне обтрунтування своӥх міркувань, висновки.

Обтрунтовано використання комплексу вправ для навчання даного виду монологічного мовлення відповідно до етапів навчання: інформативному - I комплекс вправ, дослідно-пошуковому - II комплекс вправ та презентаційному III комплекс вправ. Наведено приклади вправ до кожного етапу.

Авторка приділила увагу самостійній роботі студентів, коротко охарактеризувала даний вид навчальної діяльності за зовнішніми та внутрішніми ознаками. Також у статті йдеться про підготовку та виконання самостійної роботи. Акиентується увага на особливостях даного виду роботи, тобто планування у спеціально відведений час та різноманітність організаційних форм (спільна або індивідуальна діяльність студентів), наявність конкретних результатів, письмова, усна або комбінована форма.

Ключові слова: монологічне мовлення, медіачія, автентичні відеоматеріали, технологія конфліктного моделювання, самостійна робота, алгоритм діяльності, структура монологу. 